\title{
IMPLEMENTASI TEXT MINING UNTUK ADVERTISING DENGAN MENGGUNAKAN METODE K-MEANS CLUSTERING PADA DATA TWEETS GOJEK INDONESIA
}

\author{
Azizah Nurfauziah Yusril, Inggrit Larasati, Qurrotul Aini \\ Sistem Informasi, Fakultas Sains dan Teknologi, Universitas Islam Negeri Syarif Hidayatullah \\ Jl. Ir H. Juanda No.95, Cempaka Putih, Kecamatan Ciputat, Kota Tangerang Selatan, Banten \\ Email:azizah.ny17@mhs.uinjkt.ac.id, inggrit.larasati17@mhs.uinjkt.ac.id,qurrotul.aini@uinjkt.ac.id
}

(Diterima: 10 Juli 2020, direvisi: 15 Agustus 2020, disetujui: 31 Agustus 2020)

\begin{abstract}
In determining advertising, businesses use social media to find out the responses of their followers. Gojek Indonesia is one of the company in Indonesia who uses Twitter social media as a means to do advertising. The purpose of this research is to find out the type of tweet content that is mostly retweeted and favorite by Gojek Indonesian followers so that it can be used to do advertising to Twitter users. The collection of tweet data from Twitter is done by integrating Twitter API and $R$ programming language using $R$ Studio tools. The data analysis method uses text mining and for the clustering process uses K-means. The results of this study obtained a number of 2 cluster tweets. Based on the calculation of the average number of retweets in each cluster, it was found that the type of content with the most retweets was related to the quiz program and the introduction of Gojek Indonesia's products. Gojek Indonesia business people can use the retweet and favorite features as a means of advertising Twitter users.
\end{abstract}

Keywords: advertising, gojek indonesia, text mining, $k$-means clustering, twitter

\begin{abstract}
ABSTRAK
Dalam penentuan advertising, pelaku bisnis menggunakan media sosial untuk mengetahui respon dari para followers-nya. Gojek Indonesia merupakan salah satu pelaku bisnis di Indonesia yang menggunakan media sosial Twitter sebagai sarana untuk melakukan advertising. Tujuan dari penelitian ini yaitu untuk mengetahui jenis konten tweets yang banyak dilakukan retweet dan favorite oleh followers Gojek Indonesia sehingga dapat digunakan untuk melakukan advertising kepada pengguna Twitter. Pengumpulan data tweets dari Twitter dilakukan dengan mengintegrasikan Twitter API dan bahasa pemograman R menggunakan tools $\mathrm{R}$ Studio. Metode analisis data menggunakan text mining dan untuk klasterisasi menggunakan $K$-means. Hasil dari penelitian ini didapatkan sejumlah 2 klaster tweets. Berdasarkan perhitungan jumlah rata-rata retweet pada tiap klaster, didapatkan bahwa jenis konten dengan retweet terbanyak yaitu terkait program kuis dan perkenalan produk Gojek Indonesia. Pelaku bisnis Gojek Indonesia dapat menggunakan fitur retweet dan favorite sebagai sarana untuk melakukan advertising kepada pengguna Twitter.
\end{abstract}

Kata Kunci: advertising, gojek indonesia, text mining, $k$-means clustering, twitter

\section{PENDAHULUAN}

Sebagian besar pelaku bisnis menggunakan media sosial sebagai sarana untuk melakukan advertising. Pada gambar 1 yang diperoleh dari Statista, pengguna Twitter di Indonesia menempati urutan ke-8 di dunia dengan jumlah kurang lebih 10 juta pengguna. Twitter bisa digunakan untuk mendukung sosial media networking untuk subjek pemasaran, iklan, jurnalistik atau komunikasi subjek [1]. Sosial media analitik bisa memberikan informasi berharga bagi para pemimpin perusahaan untuk membuat keputusan strategis dan mengatasi masalah-masalah bisnis [2]. Gojek Indonesia merupakan salah satu pelaku bisnis di Indonesia yang bergerak di bidang jasa transportasi yang menggunakan media sosial Twitter sebagai sarana untuk melakukan advertising. 


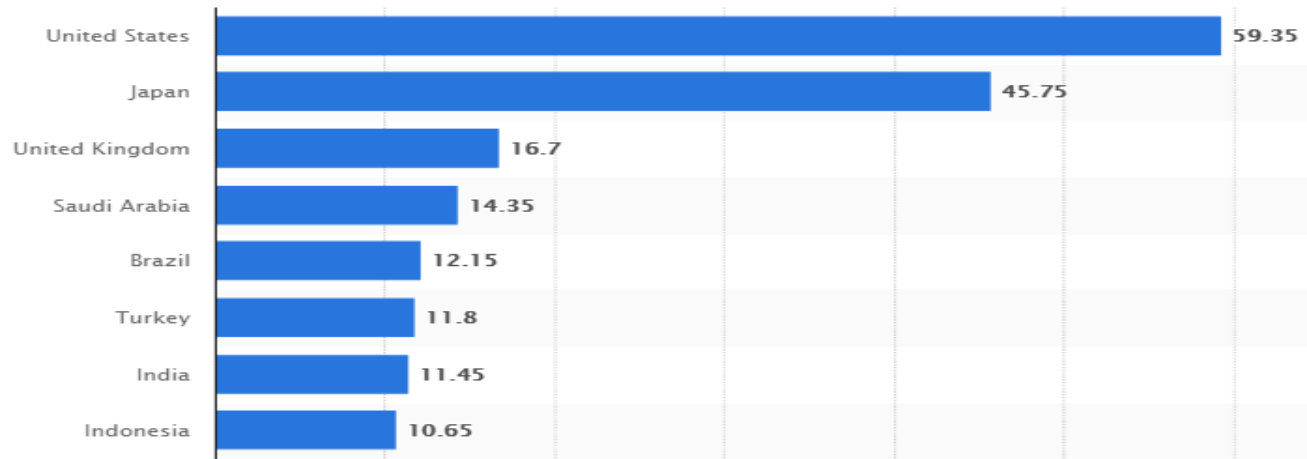

Gambar 1. Grafik Pengguna Aktif Twitter Per April 2020 [3]

Terhitung pada tanggal 9 April 2020, Gojek Indonesia memiliki jumlah followers Twitter sebanyak 946 ribu followers, dan jumlah tweets sebanyak 482 ribu. Advertising di Twitter bisa dilakukan dengan melakukan tweet promosi, akun promosi dan tren promosi. Tweet promosi adalah tweet biasa yang diiklankan oleh pengiklan dengan membayar penempatannya di Twitter. Twitter menentukan tweet promosi mana yang relevan bagi pengguna berdasarkan tweet pengguna, siapa saja yang di-follow, apa yang di-retweet, apa yang dicari, apa yang dilihat dan interaksi dengan tweet atau akun di Twitter.

Dengan fitur retweet, Gojek Indonesia bisa menerapkan viral marketing, strategi marketing yang dilakukan dengan menyebarkan infomasi produk atau layanan melalui strategi "word of mouth" atau komunikasi dari mulut ke mulut dengan memanfaatkan kecepatan penyebaran informasi. Dilihat dari aspek cost, strategi ini lebih baik karena tidak membutuhkan biaya dibanding menggunakan tweet promosi yang disediakan Twitter. Strategi ini dikatakan berhasil ketika pengguna terdorong untuk membagikan kembali informasi tersebut, misalnya dengan me-retweet kembali tweet yang dibuat oleh akun Gojek Indonesia.

Oleh karena itu penting mengetahui jenis konten tweet apa yang banyak dilakukan retweet oleh followers Gojek Indonesia. Untuk mengetahui konten iklan apa yang paling diminati oleh pengguna Twitter bisa dilakukan dengan cara text mining terhadap data tweets dengan menerapkan teknik clustering. Salah satu metode yang digunakan dalam clustering adalah metode $k$-means. Pengumpulan data tweets dari Twitter dapat dilakukan dengan mengintegrasikan Twitter API dan bahasa pemograman R dengan tools R Studio.

Text mining merupakan analisis teks dimana sumber data biasanya didapatkan dari dokumen, dan tujuannya adalah mencari kata-kata yang dapat mewakili isi dari dokumen sehingga dapat dilakukan analisa keterhubungan, keterkaitan dan kelas antar dokumen [9]. Text mining dapat didefinisikan secara luas sebagai suatu proses menggali informasi yang berasal dari sekumpulan dokumen dari waktu ke waktu menggunakan serangkaian alat analisis untuk mengidentifikasi dan mengeksplorasi pola data yang ada. Pada dasarnya text mining memiliki konsep pengolahan yang hampir sama dengan data mining, perbedaannya yaitu terdapat pada sumber data yang digunakan. Sumber data text mining berupa teks tidak terstruktur, sedangkan data mining menggunakan data terstruktur [10]. Text mining melingkupi sebuah proses ekstraksi informasi yang terpola yang berasal dari sejumlah besar sumber data teks, seperti dokumen Word, PDF, kutipan teks, atau bahkan SMS [11].

Tujuan dari penelitian ini adalah untuk mengetahui jenis konten tweet yang banyak dilakukan retweet dan favorite oleh followers Gojek Indonesia sehingga dapat digunakan sebagai sarana advertising kepada pengguna Twitter. Pengumpulan data tweets dari Twitter dilakukan dengan mengintegrasikan Twitter API dan bahasa pemograman R dengan tools R Studio, metode analisis text mining dengan menggunakan $k$-means.

\section{TINJAUAN PUSTAKA}

Pada artikel sejenis [4] dilakukan penerapan text mining untuk melakukan clustering dengan metode $k$-means pada data tweets Shopee Indonesia untuk mengetahui jenis konten tweet yang banyak dilakukan retweet oleh followers Shopee Indonesia. Hasil yang didapat adalah jenis konten pada klaster yang memiliki jumlah retweet yang tinggi diantaranya tentang kuis berhadiah (klaster 4 , 
klaster 20, dan klaster 28), ulang tahun Shopee Indonesia (klaster 11), dan hobi, kuis, dan lifestyle (klaster 7), sehingga Shopee Indonesia menggunakan jenis konten tweet tersebut untuk melakukan advertising. Pada artikel yang masih membahas e-commerce [5] aplikasi text mining ke klaster tweet dari akun Twitter @LazadaID dengan menggunakan algoritma pengelompokan modified gustafsonkessel. Hasil penelitian menunjukkan bahwa jumlah klaster optimal yang dibentuk berdasarkan indeks validasi partisi dan klasifikasi entropi klasifikasi adalah tiga klaster yang berisi penawaran barang elektronik, diskon, dan potongan harga. Tweet dengan retweet dan favorite terbanyak adalah tweet kuis hadiah. PT Lazada Indonesia dapat menggunakan tweet semacam ini untuk melakukan iklan di Twitter karena kuis hadiah disukai oleh pengikut akun Twitter @LazadaID. Pada artikel sejenis dengan objek e-commerce Lazada [6], pengumpulan data tweets dari Twitter dapat dilakukan dengan mengintegrasikan Twitter API dan RapidMiner. Metode analisis data menggunakan algoritma classic naive bayes. Hasil analisis menunjukkan hasil yang signifikan pada analisis sentimen dengan tingkat akurasi dari 98,29\%. Selanjutnya pada [7] digunakan dataset dari 10 pantai yang ada di Indonesia sebanyak 500 tweets. Hasil akurasi dari klasifikasi menggunakan algoritma support vector machine sebesar 74,39\%. Selanjutnya data opini dari kuesioner ditambahkan untuk mengelompokkan pantai berdasarkan ketersediaan sumber daya, fasilitas, akses, kesiapan masyarakat, potensi pasar dan posisi pariwisata. Proses pengelompokan data ini menggunakan metode k-means. Kemudian artikel [8] text clustering digunakan untuk mengelompokkan pendapat menjadi beberapa kategori. Metode yang digunakan adalah metode k-means dan Density Based Spatial Clustering of Applications with Noise (DBSCAN). Berdasarkan nilai silhouette coefficient, metode DBSCAN lebih baik daripada k-means dalam mengelompokkan tweet yang ditujukan kepada layanan ekspedisi JNE, J\&T, dan Pos Indonesia karena menghasilkan silhouette coefficient yang lebih tinggi.

Dari beberapa penelitian sebelumnya yang telah disebutkan diatas, $k$-means terbukti memiliki keuntungan yang lebih dibandingkan metode clustering yang lain karena tidak memerlukan iterasi yang banyak dalam proses clustering. Sehingga pada penelitian kami, $k$-means sangat cocok digunakan untuk mengetahui jenis konten tweet yang banyak dilakukan retweet dan favorite oleh followers Gojek Indonesia untuk dapat digunakan sebagai sarana advertising.

\section{METODE PENELITIAN}

Penelitian ini menggunakan metode penelitian kualitatif. Data yang digunakan yaitu data primer dan data sekunder. Data primer yang digunakan adalah dataset tweet dari Twitter. Sedangkan, data sekunder yang digunakan berupa buku, jurnal dan prosiding.

Tahap pertama di dalam penelitian ini adalah authentication untuk proses integrasi antara Twitter API dengan R. Oleh karena itu, peneliti harus mendapatkan API keys dan tokens dari Twitter terlebih dahulu dengan melakukan beberapa pengaturan di dalam platform developer Twitter yaitu https://developer.Twitter.com/en/apps. Pengaturan pertama yaitu membuat aplikasi baru dengan mengisi data-data pendukung. Setelah itu, membuat token yang diperoleh dari akun Twitter dan menyalin kode consumer key (API key), consumer secret, access token dan access token secret ke dalam aplikasi yang telah dibuat. Tahap kedua, melakukan data acquisition atau pengambilan data dari Twitter. Selanjutnya melakukan proses text mining. Tahapan di dalam text mining menurut [10] adalah:

\section{Data Prepocessing}

Tahapan ini dimana aplikasi melakukan seleksi data teks yang akan diproses. Proses yang dilakukan adalah: case folding, tokenizing, stemming dan tagging. Case folding adalah proses merubah semua huruf pada sebuah kalimat menjadi huruf kecil dan menghilangkan karakter selain huruf seperti angka, tanda baca dan Uniform Resources Locator (URL). Tokenizing adalah memotong sebuah kalimat berdasarkan tiap kata yang menyusunnya. Sedangkan Stemming adalah merubah berbagai kata berimbuhan menjadi kata dasarnya. Dan Tagging, yaitu merubah berbagai kata dalam bentuk lampau menjadi kata awalnya untuk teks dengan Bahasa Inggris.

\section{Feature Selection}

Proses yang dilakukan di tahap ini adalah stopword removal yaitu menghilangkan kata-kata yang dianggap tidak penting dari sebuah kalimat. 


\section{Text Representation}

Tahapan ini merepresentasikan sebuah kalimat sebagai objek dan kata-kata yang menyusunnya sebagai fitur. Dalam tahap ini menggunakan pendekatan bag of words atau model ruang vektor dimana sebuah model mempelajari sebuah kosakata dari seluruh dokumen, lalu memodelkan tiap dokumen dengan menghitung jumlah kemunculan setiap kata.

4. Clustering

Disini peneliti menggunakan teknik clustering dengan menggunakan metode $k$-means. $K$-means adalah salah satu teknik unsupervised clustering. Clustering dengan metode k-means mengelompokkan $n$ titik data di dalam $k$ cluster dengan meminimasi jarak antara titik data dari pusat $k$ cluster secara berulang [12]. Tahapan yang dilakukan adalah [13] : Pertama, memilih jumlah $k$ cluster secara acak. Kedua, menghitung jarak antara titik data dengan centroid (pusat cluster), jarak bisa dihitung menggunakan jarak Euclidean [14] atau pengukuran kosi [15]. Ketiga, titik data ditempatkan pada cluster yang memiliki centroid dengan jarak minimum. Keempat, setelah semua titik data ditempatkan pada cluster, centroid dihitung ulang. Terakhir, ulangi tahapan kedua sampai keempat hingga tidak menghasilkan $k$ centroid yang baru.

Flowchart metode penelitian yang digunakan oleh peneliti ditampilkan pada gambar 2.

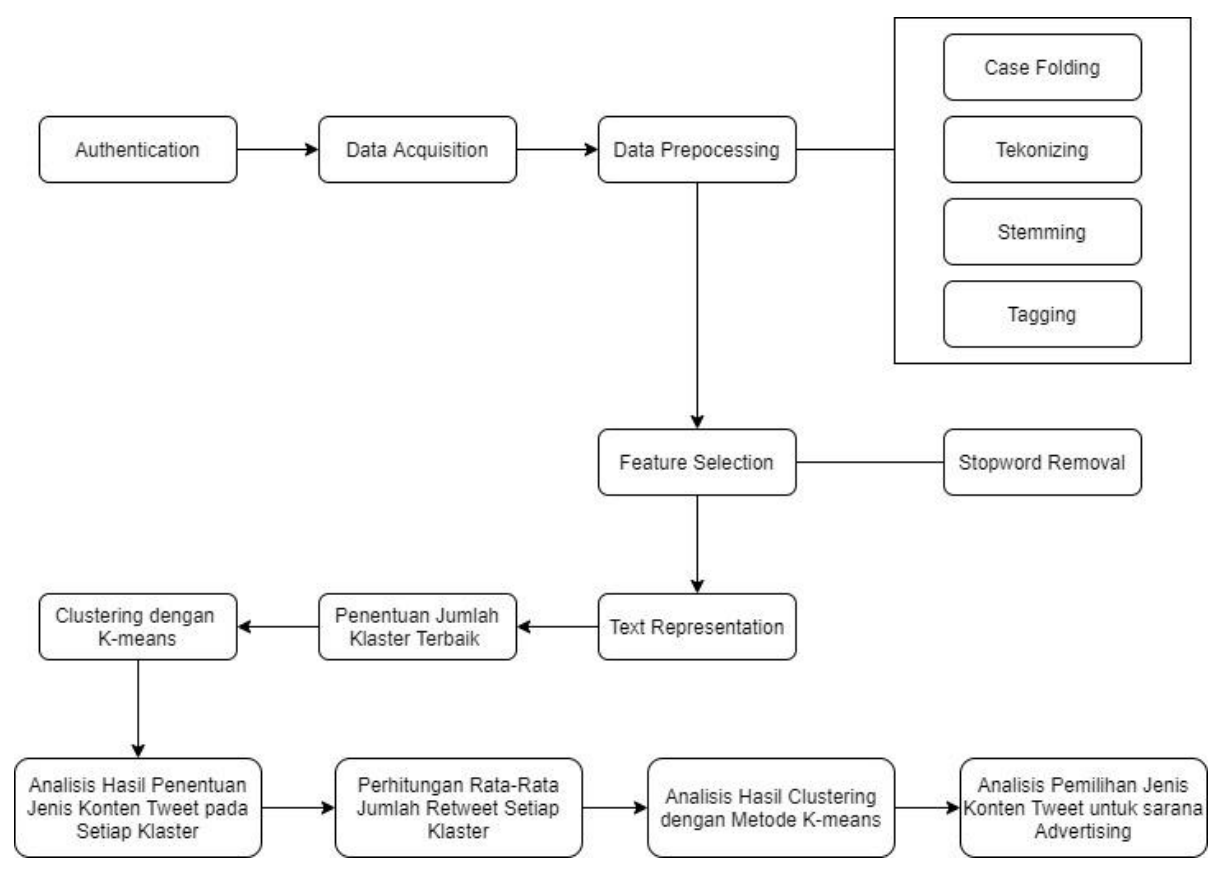

Gambar 2. Flowchart Metode Penelitian

\section{HASIL DAN PEMBAHASAN}

Algoritma proses text mining dirancang untuk melakukan clustering data tweets Gojek Indonesia. Berikut adalah tahapan proses text mining yang telah dirancang:

\section{A. Authentication}

Pada saat bergabung dengan Twitter API, akan mendapatkan sebuah kode berupa consumer key, consumer secret, dan access token, access token secret yang hanya bisa di generated satu kali. Kode yang peneliti dapat dari Twitter API ditampilkan pada tabel 1.

Tabel 1. Kode Yang Didapat Dari Twitter API

\begin{tabular}{ll}
\hline \hline Consumer Key & vNS8jrAaZFQ2bx103y3ODJclo \\
Consumer Secret & W1ZoXlo0s4LwZ60uhA3QEmKG1bnislIOS9uuZHUg6j70QpPfgs \\
Acess Token & 1262217708998815744-U0agi1BQ7yKh0FkJttcZBJsoeovCgo \\
Acces Token Secret & C4h9Ho6kgDbZJFpjaGrLfWnL22YFLK2zvASsyRviPIdWD \\
\hline \hline
\end{tabular}


Kode di atas digunakan untuk proses integrasi antara Twitter API dengan R, dimana proses integrasi dilakukan dengan menggunakan fungsi: 'setup_Twitter_auth (consumer_key, consumer_secret, access_token, access_token_secret)'

\section{B. Data Acquisition}

Pada tabel 2, adalah contoh data tweets yang ditampilkan dari timeline Twitter Gojek Indonesia dimana pengambilan data dilakukan secara real time menggunakan package TwitteR dengan syntax yaitu Tweet <-userTimeline ("GojekIndonesia", $\mathrm{n}=3200$, excludeReplies= TRUE). Data yang di crawling menghasilkan 84 tweets per tanggal 5 juni 2020.

Tabel 2. Contoh Data Tweets Yang Ditampilkan Dari Timeline Twitter Gojek Indonesia

\begin{tabular}{|c|c|c|c|}
\hline $\begin{array}{c}\text { Nomer } \\
\text { Tweet }\end{array}$ & Teks Tweet & $\begin{array}{c}\text { Tanggal } \\
\text { Tweet }\end{array}$ & $\begin{array}{c}\text { Jumlah Retweets/ } \\
\text { Comments/Favorites }\end{array}$ \\
\hline 1 & $\begin{array}{l}\text { Cus gaes... pesen makanan yang } \\
\text { kamu mau di GoFood sekarang, biar } \\
\text { dapet DISKON SAMPE } 70 \% \text { dari } \\
\text { promo \#HARKULNASGOFOOD! } \\
\text { Nikmatin promonya \#dirumahaja } \\
\text { mulai dari } 1 \text { April sampai } 5 \text { Mei } \\
2020 \text {;) https://t.co/6oQSfi8RFP }\end{array}$ & $\begin{array}{l}2020-\quad 04- \\
02 \\
04: 57: 34\end{array}$ & $\begin{array}{l}\text { Retweets }=10 \\
\text { Comments }=13 \\
\text { Favorites }=41\end{array}$ \\
\hline 2 & $\begin{array}{l}\text { Gaes, ada kabar baik nih. Sekarang, } \\
\text { kamu bisa belanja sembako murah } \\
\text { buat kebutuhan puasa lewat aplikasi } \\
\text { Gojek loh. Iya, ini aku kerja sama } \\
\text { dengan @ kementan gitu. Cek cara } \\
\text { belanja di "Pasar Mitra Tani" via } \\
\text { GoFood di video ini ya. Foto: dok. } \\
\text { Badan Ketahanan Pangan } \\
\text { https://t.colaFnONqpJiT }\end{array}$ & $\begin{array}{l}2020-04- \\
23 \\
11: 44: 34\end{array}$ & $\begin{array}{l}\text { Retweets }=38 \\
\text { Comments }=16 \\
\text { Favorites }=52\end{array}$ \\
\hline
\end{tabular}

\section{Case Folding}

Pada proses case folding, dilakukan beberapa fungsi seperti yang ditampilkan pada tabel 3 . Untuk contoh hasil proses case folding ditampilkan pada tabel 4 .

\section{Tabel 3. Fungsi Di Dalam Case Folding}

\begin{tabular}{|c|c|c|}
\hline No & Fungsi & Syntax \\
\hline 1 & $\begin{array}{l}\text { Ubah huruf kapital } \\
\text { menjadi huruf kecil }\end{array}$ & $\begin{array}{l}\text { corpusdokclean }<- \text { tm_map(corpusdok, } \\
\text { content_transformer(tolower)) }\end{array}$ \\
\hline 2 & Hapus Angka & $\begin{array}{l}\text { corpusdokclean }<- \text { tm_map(corpusdokclean, } \\
\text { content_transformer(removeNumbers)) }\end{array}$ \\
\hline 3 & Hapus URL & $\begin{array}{l}\text { removeURL <- function(x) gsub("http[^[:space:]]*", "",x) } \\
\text { corpusdokclean <- tm_map(corpusdokclean, } \\
\text { content_transformer(removeURL)) }\end{array}$ \\
\hline 4 & Hapus Mention & $\begin{array}{l}\text { remove.mention <- function(x) gsub("@ @IIS+", "", x) } \\
\text { corpusdokclean <- tm_map(corpusdokclean, } \\
\text { remove.mention) }\end{array}$ \\
\hline 5 & Hapus Hashtag & $\begin{array}{l}\text { remove.hashtag <- function(x) gsub("\#॥IS+", "", x) } \\
\text { corpusdokclean <- tm_map(corpusdokclean, } \\
\text { remove.hashtag) }\end{array}$ \\
\hline 6 & Hapus Tanda Baca & $\begin{array}{l}\text { corpusdokclean<- } \\
\text { tm_map(corpusdokclean,content_transformer(removePun } \\
\text { ctuation)) }\end{array}$ \\
\hline
\end{tabular}


Tabel 4. Contoh Hasil Proses Case Folding

\begin{tabular}{cl}
\hline $\begin{array}{c}\text { Nomor } \\
\text { Tweet }\end{array}$ & \multicolumn{1}{c}{ Teks Tweet Hasil Case Folding } \\
\hline 1 & $\begin{array}{l}\text { cus gaes pesen makanan yang kamu mau di gofood sekarang biar dapet diskon sampe } \\
\text { dari promo harkulnas gofood nikmatin promonya dirumahaja mulai dari april sampai } \\
\text { mei }\end{array}$ \\
2 & $\begin{array}{l}\text { gaes ada kabar baik nih sekarang kamu bisa belanja sembako murah buat kebutuhan } \\
\text { puasa lewat aplikasi gojek loh iya ini aku kerja sama dengan kementan gitu cek cara } \\
\text { belanja di pasar mitra tani via gofood di video ini ya foto dok badan ketahanan pangan }\end{array}$
\end{tabular}

\section{Tokenizing}

Pada proses tokenizing, pemotongan kalimat pada tweet berdasarkan tiap kata yang menyusunnya dilakukan dengan menggunakan fungsi: tdm <TermDocumentMatrix (corpusdokclean, control $=\operatorname{list}($ wordLengths $=c(1$, Inf $)))$. Contoh hasil proses tokenizing ditampilkan pada tabel 5.

Tabel 5. Contoh Hasil Proses Tokenizing

\begin{tabular}{|c|c|c|c|}
\hline $\begin{array}{c}\text { Nomor } \\
\text { Tweet }\end{array}$ & Hasil Tokenizing & $\begin{array}{c}\text { Nomer } \\
\text { Tweet }\end{array}$ & Hasil Tokenizing \\
\hline 1 & $\begin{array}{l}\text { cus } \\
\text { gaes } \\
\text { pesen } \\
\text { makanan } \\
\text { yang } \\
\text { kamu } \\
\text { mau } \\
\text { di } \\
\text { gofood } \\
\text { sekarang } \\
\text { biar } \\
\text { dapet } \\
\text { diskon } \\
\text { sampe } \\
\text { dari } \\
\text { promo } \\
\text { harkulnas } \\
\text { gofood } \\
\text { nikmatin } \\
\text { promonya } \\
\text { dirumahaja } \\
\text { mulai } \\
\text { dari } \\
\text { april } \\
\text { sampai } \\
\text { mei }\end{array}$ & 2 & $\begin{array}{l}\text { Gaes } \\
\text { ada } \\
\text { kabar } \\
\text { baik } \\
\text { nih } \\
\text { sekarang } \\
\text { kamu } \\
\text { bisa } \\
\text { belanja } \\
\text { sembako } \\
\text { murah } \\
\text { buat } \\
\text { kebutuhan } \\
\text { puasa } \\
\text { lewat } \\
\text { aplikasi } \\
\text { gojek } \\
\text { loh } \\
\text { iya } \\
\text { ini } \\
\text { aku } \\
\text { kerja } \\
\text { sama } \\
\text { dengan } \\
\text { kementan } \\
\text { gitu } \\
\text { cek } \\
\text { cara } \\
\text { belanja } \\
\text { di } \\
\text { pasar }\end{array}$ \\
\hline
\end{tabular}




\begin{tabular}{ll}
\hline & mitra \\
& tani \\
via & gofood \\
di & video \\
ini \\
ya \\
foto \\
dok \\
badan \\
ketahanan \\
pangan
\end{tabular}

\section{E. Stopword Removal}

Pada proses stopword removal, penghilangan kata-kata yang dianggap tidak penting atau tidak menggambarkan isi dari sebuah tweet dilakukan dengan menggunakan fungsi: cleanset <tm_map(corpusdok, removeWords, cStopwordID). Untuk contoh hasil proses stopword removal ditampilkan pada tabel 6.

Tabel 6. Contoh Hasil Proses Stopword Removal

\begin{tabular}{|c|c|c|c|}
\hline $\begin{array}{c}\text { Nomor } \\
\text { Tweet }\end{array}$ & $\begin{array}{c}\text { Hasil Stopword } \\
\text { Removal }\end{array}$ & $\begin{array}{c}\text { Nomer } \\
\text { Tweet }\end{array}$ & $\begin{array}{c}\text { Hasil Stopword } \\
\text { Removal }\end{array}$ \\
\hline 1 & $\begin{array}{l}\text { cus } \\
\text { gaes } \\
\text { pesen } \\
\text { makanan } \\
\text { gofood } \\
\text { biar } \\
\text { dapet } \\
\text { diskon } \\
\text { sampe } \\
\text { promo } \\
\text { harkulnas } \\
\text { gofood } \\
\text { nikmatin } \\
\text { promonya } \\
\text { dirumahaja } \\
\text { april } \\
\text { mei }\end{array}$ & 2 & $\begin{array}{l}\text { Gaes } \\
\text { kabar } \\
\text { nih } \\
\text { belanja } \\
\text { sembako } \\
\text { murah } \\
\text { kebutuhan } \\
\text { puasa } \\
\text { aplikasi } \\
\text { gojek } \\
\text { loh } \\
\text { iya } \\
\text { kerja } \\
\text { kementan } \\
\text { gitu } \\
\text { cek } \\
\text { belanja } \\
\text { pasar } \\
\text { mitra } \\
\text { tani } \\
\text { via } \\
\text { gofood } \\
\text { video } \\
\text { ya } \\
\text { foto } \\
\text { dok } \\
\text { badan } \\
\text { ketahanan } \\
\text { pangan }\end{array}$ \\
\hline
\end{tabular}

\section{F. Text Representation}


Pada proses text representation, perubahan data tweet menjadi sebuah matriks dimana baris berupa nomor dari tweet dan kolom berupa kata penyusun dari data tweet dengan menggunakan fungsi: $\mathrm{m}<-$ as.matrix $(\mathrm{tdm})$. Berdasarkan hasil text representation, banyaknya seluruh kata yang menyusun 84 tweets dari Gojek Indonesia adalah sebanyak 391 kata. Untuk hasil proses text representation ditampilkan pada tabel 7 .

Tabel 7. Contoh Hasil Proses Text Representation

\begin{tabular}{ccccccc}
\hline $\begin{array}{c}\text { Nomor } \\
\text { Tweet }\end{array}$ & dirumahaja & Gaes & Hobi & ngeliat & ngeshare & penasaran \\
\hline 1 & 1 & 1 & 1 & 1 & 1 & 1 \\
2 & 0 & 1 & 0 & 0 & 0 & 0 \\
3 & 0 & 0 & 0 & 0 & 0 & 0 \\
4 & 0 & 0 & 0 & 0 & 0 & 0 \\
5 & 0 & 1 & 0 & 0 & 0 & 0
\end{tabular}

\section{G. Penentuan Jumlah Klaster Terbaik}

Gambar 3 merupakan nilai silhouette coefficient yang dilakukan berdasarkan hasil perhitungan dengan menggunakan fungsi: 'fviz_nbclust (tdm, kmeans, method = "silhouette", k.max=10)'. Perhitungan nilai silhouette coefficient dilakukan untuk $\mathrm{k}=1$ sampai $\mathrm{k}=10$ dan didapat $\mathrm{k}$ terbaik adalah $\mathrm{k}=2$. Hasil perhitungan $\mathrm{k}$ terbaik digunakan untuk proses clustering dengan $k$-means.

\section{Optimal number of clusters}

\section{Silhouette Method}

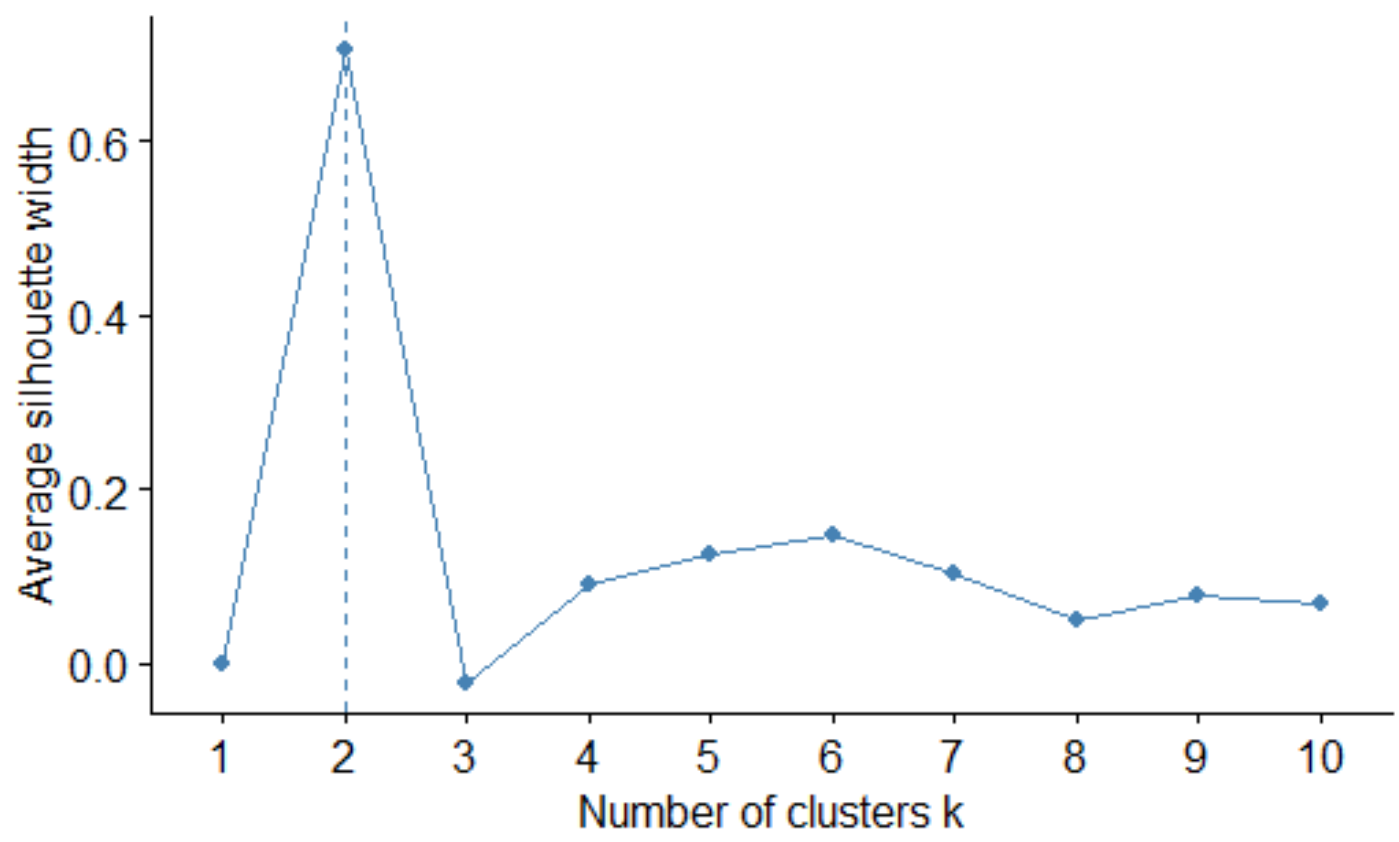

Gambar 3. Nilai Silhouette Coefficient Pada Jumlah Klaster Sebanyak 1 Sampai 10

\section{H. Clustering dengan K-means}

Pada proses clustering dengan $k$-means dengan menggunakan fungsi: 'kmeans $\mathrm{i}=$ kmeans (tdm, $2,100)$ ' dengan jumlah klaster sebanyak 2 klaster dan jumlah iterasi sebanyak 100 iterasi. Untuk hasil clustering dengan k-means ditampilkan pada tabel 8. 
Tabel 8. Hasil Clustering Dengan K-Means

\begin{tabular}{clc}
\hline $\begin{array}{c}\text { Nomor } \\
\text { Klaster }\end{array}$ & \multicolumn{1}{c}{ Nomor Tweet } & $\begin{array}{c}\text { Jumlah } \\
\text { Tweets }\end{array}$ \\
\hline 1 & $9,25,38$ & 3 \\
2 & $1,2,3,4,5,6,7,8,10,11,12,13,14,15,16,17,18,19$, & 81 \\
& $20,21,22,23,24,26,27,28,29,30,31,32,33,34,35,36$, & \\
& $37,39,40,41,42,43,44,45,46,47,48,49,50,51,52,53$, & \\
& $54,55,56,57,58,59,60,61,62,63,64,65,66,67,68,69$, & \\
& $70,71,72,73,74,75,76,77,78,79,80,81,82,83,84$ &
\end{tabular}

\section{Analisis Hasil Penentuan Jenis Konten Tweet pada Setiap Klaster}

Proses pemilihan kata yang paling sering muncul pada masing-masing klaster dilakukan dengan menggunakan fungsi: freq <- rowSums $(\mathrm{tdm})$ freq <- subset (freq, freq $>=3$ ) freq. Untuk hasil dari proses tersebut ditampilkan pada tabel 9.

Tabel 9. Kata Paling Sering Muncul Dan Jenis Konten Tweet Pada Setiap Klaster

\begin{tabular}{cll}
\hline $\begin{array}{l}\text { Nomor } \\
\text { Klaster }\end{array}$ & \multicolumn{1}{c}{ Kata Paling Sering Muncul } & Jenis Konten Tweet \\
\hline 1 & $\begin{array}{l}\text { gojek, selamat, driver, konser, ramadan, semangat, } \\
\text { indonesia } \\
\text { gaes, ebadah, newprofilpic, template, judul, ikutan, komik, } \\
\text { cus, kuis, merapat, tweet, musafir, dialog }\end{array}$ & $\begin{array}{l}\text { Rewarding, konser, } \\
\text { ramadan }\end{array}$ \\
Ajakan, produk \\
gojek, dan kuis
\end{tabular}

\section{J. Perhitungan Rata-Rata Jumlah Retweet Setiap Klaster}

Pada tabel 10, merupakan hasil dari proses perhitungan rata-rata jumlah retweet tiap klaster dilakukan terhadap hasil dari clustering dengan $k$-means.

Tabel 10. Perhitungan Rata-Rata Jumlah Retweet Setiap Klaster

\begin{tabular}{cccc}
\hline $\begin{array}{l}\text { Nomor } \\
\text { Klaster }\end{array}$ & Jumlah Tweets & Total Retweets & Rata-rata Retweet \\
\hline 1 & 3 & 112 & 37,333 \\
2 & 81 & 3833 & 47,320
\end{tabular}

\section{K. Analisis Hasil Clustering dengan Metode K-means}

Salah satu metode yang digunakan untuk menguji kualitas klaster yang dihasilkan dari proses clustering adalah silhouette coefficient. Pada tabel 11 ditampilkan hasil dari perhitungan silhouette coefficient pada setiap klaster tweet.

Tabel 11. Perhitungan Silhouette Coefficient Pada Setiap Klaster Tweet

\begin{tabular}{ccc}
\hline $\begin{array}{l}\text { Nomor } \\
\text { Klaster }\end{array}$ & Jumlah Tweets & Nilai Shilloutte Coeficient \\
\hline 1 & 3 & 0,0 \\
2 & 81 & 0,7
\end{tabular}

Pada gambar 3, dapat dilihat nilai shiloutte coefficient pada 2 klaster. Diketahui sebanyak 1 klaster memiliki nilai positif dan 1 klaster memiliki nilai 0 . Nilai positif menunjukkan bahwa sebagian besar anggota pada klaster berada pada klaster yang tepat, nilai 0 menunjukkan bahwa sebagian besar anggota pada klaster berada di antara 2 klaster.

Azizah Nurfauziah Yusril dkk : Implementasi Text Mining Untuk Advertising Dengan Menggunakan Metode K-Means Clustering Pada Data Tweets Gojek Indonesia 
Terdapat beberapa faktor yang membuat hasil clustering dengan metode $k$-means pada data tweet masih belum optimal, diantaranya adalah sebagai berikut:

1. Batas maksimal karakter yang ada pada sebuah tweet adalah 280 karakter, sehingga sebagian besar tweet mengandung kata-kata yang berupa singkatan. Contoh: seharusnya kata "sosial media" menjadi "sosmed", "by the way" menjadi "btw". Penggunaan kata singkatan berpengaruh terhadap proses stopword removal, dimana kata yang seharusnya dihilangkan menjadi tidak terdeteksi sehingga akan tetap ada pada kalimat $t$ weet.

2. Tidak dilakukannya proses stemming dan tagging berakibat pada adanya kata-kata yang serupa maknanya namun beda dalam penulisan hurufnya. Contoh: kata "cus" dengan "cuss". Yang menyebabkan kata ini berada di klaster yang berbeda padahal memiliki arti atau makna yang sama. Selain itu, masih terdapat kata yang berimbuhan. Contoh: "kebutuhan".

\section{Analisis Pemilihan Jenis Konten Tweet untuk Sarana Advertising}

Berdasarkan hasil perhitungan jumlah retweet pada tiap klaster, didapatkan bahwa jenis konten pada klaster yang memiliki jumlah retweet yang tinggi diantaranya tentang ajakan mengikuti kuis dan perkenalan produk dari Gojek Indonesia. Sedangkan jenis konten pada klaster yang memiliki jumlah retweet yang rendah mengenai rewarding, konser dan Ramadhan.

Hasil yang didapatkan menunjukkan bahwa pelanggan dari Gojek Indonesia lebih tertarik pada program kuis dibandingkan dengan hal yang membahas mengenai rewarding, konser dan Ramadhan. Selain itu untuk memperoleh respon dari followers Gojek Indonesia, tweet yang dibuat oleh Gojek Indonesia sebaiknya berisi hal yang sedang hangat diperbincangkan di masyarakat.

\section{KESIMPULAN}

Penerapan algoritma proses text mining untuk melakukan clustering dengan metode k-means pada data tweets Gojek Indonesia menghasilkan 2 klaster optimal. Berdasarkan perhitungan rata-rata jumlah retweet pada tiap klaster, didapatkan bahwa jenis konten pada klaster yang memiliki jumlah retweet terbanyak yaitu mengenai program kuis, dan perkenalan produk milik Gojek Indonesia. Pelaku bisnis Gojek Indonesia dapat mengetahui jenis konten tweet yang banyak dilakukan retweet dan favorite oleh followers-nya sehingga dapat menggunakan jenis konten tweet tersebut sebagai sarana untuk melakukan advertising kepada pengguna Twitter. Untuk penelitian selanjutnya, sebaiknya dilakukan proses stemming dan tagging agar hasil clustering yang didapatkan lebih optimal.

\section{REFERENSI}

[1] D. Mccorkle And J. Payan, "Using Twitter In The Marketing And Advertising Classroom To Develop Skills For Social Media Marketing And Personal Branding," J. Advert. Educ., vol. 21, no. 1, pp. 33-43, May 2017, Doi: 10.1177/109804821702100107.

[2] D. M. Carpenter, J. W. Robertson, M. E. Johnson, And S. Blum, "Social Media Analytics In Education: What Is It, How Is It Useful, And What Does It Tell Us About How Schools Are Discussed In Social Media?," J. Sch. Public Relat., vol. 35, no. 1, pp. 7-43, Jan. 2014, Doi: 10.3138/Jspr.35.1.7.

[3] "Leading Countries Based On Number Of Twitter Users As Of April 2020," available : https://www.statista.com/statistics/242606/number-of-active-Twitter-users-in-selected-countries/, [Diakses : 18 mei 2020].

[4] D. S. Indraloka And B. Santosa, "Penerapan Text Mining Untuk Melakukan Clustering Data Tweet Shopee Indonesia," J. Sains Dan Seni Its., vol. 6, no. 2, pp. a51-a56, Sep. 2017, Doi: 10.12962/J23373520.V6i2.24419.

[5] R. K. Putri And B. Warsito, "Implementasi Algoritma Modified Gustafson-Kessel Untuk Clustering Tweet Pada Akun Twitter Lazada Indonesia," vol. 8, no. 3, p. 11, 2019.

[6] S. Dodi, and S. Iin, " Analisis Sentimen Masyarakat Terhadap data Tweet Lazada Menggunakan Text Mining Dan Algoritma Naive Bayes Classifier," Bina Darma Conference on Computer Science., e-ISSN: 2685-2683p-ISSN: 2685-2675. 
[7] Y. W. Syaifudin And R. A. Irawan, "Implementasi Analisis Clustering Dan Sentimen Data Twitter Pada Opini Wisata Pantai Menggunakan Metode K-Means," J. Inform. Polinema., vol. 4, no. 3, p. 189, May 2018, Doi: 10.33795/Jip.V4i3.205.

[8] I. Putri and Irhamah, "Text Clustering pada Akun Twitter Layanan Ekspedisi JNE, J\&T, dan Pos Indonesia Menggunakan Metode Density-Based Spatial Clustering of Applications with Noise (DBSCAN) dan K-Means," Jurnal Sains Dan Seni ITS., vol. 8, no. 2, 2019.

[9] B. Lantz, "Machine Learning With R: Learn How To Use R To Apply Powerful Machine Learning Methods And Gain An Insight Into Real-World Applications," Birmingham: Packt Publ., 2013.

[10]R. Feldman And J. Sanger, "The Text Mining Handbook: Advanced Approaches In Analyzing Unstructured Data," Cambridge; New York: Cambridge University Press., 2007.

[11]Hartanto, " Text Mining Dan Sentimen Analisis Twitter Pada Gerakan LGBT", 2017.

[12]J. Kogan, M. Teboulle, And C. Nicholas, "Data Driven Similarity Measures For K-Means Like Clustering Algorithms," Inf. Retr., vol. 8, no. 2, pp. 331-349, Apr. 2005, Doi: 10.1007/S10791005-5666-8.

[13]S. Ahuja And G. Dubey, "Clustering And Sentiment Analysis On Twitter Data," p. 5, 2017.

[14]J. Macqueen, "Some Methods For Classification And Analysis Of Multivariate Observations," Multivar. Obs., p. 17.

[15]L. Sahu And B. R. Mohan, "An Improved K-Means Algorithm Using Modified Cosine Distance Measure For Document Clustering Using Mahout With Hadoop," In 2014 9th International Conference On Industrial And Information Systems (Iciis), Gwalior, India., pp.1-5, Dec. 2014, Doi: 10.1109/Iciinfs.2014.7036661. 